\title{
PSYCHE
}

VOL. XXIV

AUGUST, 1917

No. 4

\section{EIGHT NEW MALLOPHAGA OF THE GENUS LIPEURUS FROM NORTH AMERICAN BIRDS.}

\section{By E. A. McGregor,}

Bureau of Entomology, U. S. Department of Agriculture.

Lipeurus brevicephalus sp. nov.

Two females, two males, and two immature individuals (McGregor No. 101, Washburn No. 166) from sand-hill crane (Grus mexicana), western Minnesota, April 15, 1894.

This species is nearest $L$. hebrceus $\mathrm{N}$. (from Grus cinera and G. pavonina) from which it is very distinct. It also superficially resembles $L$. toxoceros $\mathrm{N}$. which is from an entirely different host.

Description of Male. Total length, $4.76 \mathrm{~mm}$.; length of head, $1.045 \mathrm{~mm}$.; length of prothorax, $.357 \mathrm{~mm}$.; length of metathorax, $.797 \mathrm{~mm}$.; length of abdomen, $2.585 \mathrm{~mm}$.; width of head across temples, $.907 \mathrm{~mm}$.; width of prothorax, $.660 \mathrm{~mm}$.; width of metathorax, .962 mm.; width of abdomen, .990.

Head slightly longer than wide, rather abruptly narrowed anteriorly, with a truncate frontal margin, antennal sinuses very shallow, temples some what rounding, eyes strongly projecting, hindhead widest half way between the eyes and the posterior angles, occipital margin strongly concave, four long marginal hairs and two short ones before the antennal angle, a prickle arises from the eye, one longish hair and five prickles on the temporal margin, and a pair of prickles arise dorsally from the forehead; head pale, antennal bands arise just before the antennæ and are lost in the colored areas which extend laterally from the mandibles, but reappear as narrow borders behind the eyes. What appear to be faint occipital bands extend toward the bases of the mandibles. Antennæ with segment 1 greatly swollen and equal to all the other segments; segment 3 with a dorsal, distal appendage and with a dorsal, proximal, annulated gland. 
Thorax one-fifth longer than wide. Prothorax trapezoidal, with posterior margin nearly straight. A weak spine at the posterior lateral angle. Metathorax at first converges slightly and then widens to the abdomen; posterior margin twice weakly concave forming a weak median angle; a series of five long hairs in the posterior angles, and on each side between the latter and the middle a series of four similar hairs; central and hind portion of prothorax and central portion of metathorax yellow-amber colored. Legs ample, yellowish, pale margined.

Abdomen slender, elongate, slightly widening to segment 5, then tapering gradually to segment 9 ; segment 1 conspicuously shorter than the others; segments 2 to 8 with transparent lateral plates immediately within which occur longitudinal bands of darker color; general color pale amber. Segment 2 with a short spine at the posterior angles; segment 3 with three similar spines at the posterior angles; segment 4 with a spine and a longer hair at the posterior angles; segment 5 with one long and two shorter hairs at angles; segment 6 with three shortish hairs at angles; segment 7 with three longish hairs at angles; segment 8 with two longish hairs at the posterior lateral angles, one just within the lateral plate, and four along the posterior border; segment 9 very deeply notched, forming a pair of terminal claw-like appendages at the inner borders of which near the base are a pair of shortish hairs, while a series of six short hairs occur laterally thereon.

Type: Catalogue No. 21369, U. S. Nat. Museum.

Lipeurus crotophagæ sp. nov.

One female (Bishopp No. 916) from groove-billed ani (Crotophaga sulcirostris), Victoria, Mexico, December 10, 1909, collector F. C. Bishopp.

Not much resembling $L$. macgragori Kell. from same host, but probably nearest $L$. variegatus Neumann and $L$. picturatus Kell. The present species is very distinct from all of these.

Description of Female. Total length, $1.44 \mathrm{~mm}$.; length of head, $.455 \mathrm{~mm}$; l length of prothorax, .104 mm.; length of metathorax, $.182 \mathrm{~mm}$.; length of abdomen, $832 \mathrm{~mm}$.; width of head, $.429 \mathrm{~mm}$.; width of prothorax, $.260 \mathrm{~mm}$; ; width of metathorax, .364 mm.; width of abdomen, $.598 \mathrm{~mm}$.

Head roughly pentagonal, a trifle longer than wide, converging 
abruptly to a narrow frontal margin bordered on each side by two shortish hairs. Between the trabeculæ, which are quite prominent, and the frontal border five prickles arise. Antennal sinuses hardly noticeable. Ocular projections barely discernible; ocular fleck conspicuous. Temple margins diverge slightly posteriorly to the squarish angles which bear a strong spine; a prickle arises from the eye, and two from the temples. Occipital margin almost straight, but with a weak median convexity. Antennal bands clearest just before the antennæ, paling anteriorly and separated at front by the large, median, dark-bordered clear area which extends back to the mandibles. Temples narrowly margined by blackish borders. Faint bands running backward from the trabeculæ and the mandibles unite posteriorly to form a W-shaped figure. A diamond-shaped occipital signature. Antennæ conventional.

Thorax one-fourth wider than long, prothorax rectangular withvery slightly convex posterior margin. A short spine at each posterior lateral angle. Smoky-amber color with a median clear area, and with narrow, dark, underlying bands. Metathorax pentagonal, sides diverging strongly to the angulated posterior margin. A strong postulated spine at the lateral posterior angle, and four long, postulated hairs along each lateral third of the hind border. Color smoky-brown, with a median, vase-shaped, olear area. Legs smoky banded.

Abdomen widely elliptical, widest on the fourth segment. General color hyaline with a dorsal series of paired, sub-quadrate, brownish plates, and with lateral plates of slightly darker color on segments 2 to 7 inclusive; the dorsal plates on segment 1 larger and darker than others. Marginal hairs at posterior lateral angles as follows: Two weak hairs on segment 3, two longer ones on segment 4 , two long hairs on each of segments $5,6,7$ and 9 , one long hair on segment 8. A median pair of long spines on segments 1 to 8 inclusive. A pair of weak terminal hairs. Segmental sutures mostly invisible.

Type: Catalogue No. 21363, U. S. Nat. Mus.

Lipeurus mississippiensis sp. nov.

One female (Bishop No. 4053) from flicker, Hamburg, Miss., December 24, 1914, coll. W. E. Dove. 
This conspicuously marked species is nearest $L$. snodgrassi Kell. (of humming-bird) and L. stramineus Denny (of woodpecker), but from both of these our species is very distinct.

Description of Female. Total length, 1.62 mm.; length of head, $.477 \mathrm{~mm}$.; length of prothorax, $.108 \mathrm{~mm}$.; length of metathorax $.162 \mathrm{~mm}$.; length of abdomen, .882 mm.; width of head across temples, $.342 \mathrm{~mm}$.; width of prothorax, $.270 \mathrm{~mm}$.; width of metathorax, $.360 \mathrm{~mm}$.; width of abdomen, $.432 \mathrm{~mm}$.

Head fully a third longer than wide, rhombic-rectangular in outline, forehead slightly narrowed to the wide, rounded front, temples converging rotundately to the very slightly concave occiput. Antennal sinuses rather shallow. Trabeculæ quite prominent. Ocular projections not very noticeable. Antennal bands extremely conspicuous as wide, dark areas bordering the forehead, but paling anteriorly and interrupted across the frontal margin by the large, quadrilateral, clear area before the mandibles; continuing paler around the antennal bases to the temporal marginal bands which are as dark as the antennal bands but somewhat narrower; both of these bands are bordered inwardly by conspicuous pustulations. Occipital border without color. Backward pointing bars resembling occipital bands extend from the antennal bands part way to the occiput. An obelisk-shaped occipital signature plainly visible. A strong hair at each angle of the frontal border, two shorter hairs before each trabecula, a prickle on the eye, two long hairs on the hind portion of temples, a pair of prickles dorsally on the forehead, and a similar pair dorsally between the eyes. Excepting the antennal, temporal and occipital bands, the mandibles, the oesophageal sclerite and the occipital signature, and the smoky temples, the head color is transparent. Antennæ normal, segments $1,3,4$ and 5 smoky banded.

Thorax one-third again as wide as long. Prothorax rectangular with front and hind margins almost straight. A strong hair at each posterior lateral angle. Wide, dark, submarginal bands extending nearly to occipital signature, within which are underlying smoky areas, separated by a median clear area. Metathorax quite strongly diverging to the twice weakly emarginated posterior border. A strong and a weak spine at each angle, and a transverse series of twelve long hairs along the hind margin. Inward curving, black, submarginal bands, further bordered by 
dark-brown which involves the entire segment excepting a central, clear, urn-shaped area. Legs conventional, pitchy bordered.

Abdomen clavate, widest on the fifth segment. Segments 1 to 7 each with black, lateral plates which reach well into the segment ahead, and with wide, brown, blotches within the plates with deeply indented inner margins. Segments 4 and 5 each with a faint central blotch, and a $\mathrm{T}$-shaped blotch involving segments 6 to 9 inclusive. The posterior lateral angles of segments 3 to 7 supplied with hairs as follows: Segment 3, a weak prickle; segment 4, a prickle and a long hair; segment 5, two long hairs; segment 6, two long hairs; segment 7, a short and a long hair. Segment 8 with a long hair at middle of lateral margin; segment 9 with a terminal fringe of 14 long hairs; segments $2,3,4,5,6$ and 8 with a long hair arising just within the head of the lateral plate; segments 1 to 7 inclusive with dorsal transverse spines as follows: Segment 1, four; segment 2, two; segment 3, two; segment 4, four; segment 5 , five; segment 6 , three; segment 7 , four.

Type: Catalogue No. 21368, U. S. Nat. Mus.

\section{Lipeurus texanus n. sp.}

One female (Bishopp No. 3244) from meadow lark, Gainesville, Texas, November 26, 1915, coll. F. C. Bishopp, and one immature individual (Bishopp No. 4015) from turtle dove, Uvalde, Texas, November 20, 1914, coll. Parman \& Bishopp.

This species is nearest $L$. baculus $\mathrm{N}$., from which it is very distinct as follows: Occipital margin of head, general shape and

Drawings by the author. Made through use of camera lucida with little attempt to restore symmetry.

\section{Explanation of Plate.} Plate V.

Fig. 1. Female of Lipeurus mississippiensis sp. nov.

2. Male of Lipeurus brevicephalus sp. nov.

3. Left leg III of male of Lipeurus brevicephalus sp. nov. (viewed ventrally).

4. Female of Lipeurus crotophaga sp. nov.

5. Right leg III of female of Lipeurus mississippiensis sp. nov. (viewed ventrally). 
posterior margin of metathorax, outline of abdomen, and peculiar abdominal lateral plates.

Description of Female. Total length, $1.55 \mathrm{~mm}$.; length of head, $.466 \mathrm{~mm}$.; length of prothorax, $.095 \mathrm{~mm}$.; length of metathorax, $.206 \mathrm{~mm}$.; length of abdomen, .784 mm.; width of head across temples, $.286 \mathrm{~mm}$.; width of prothorax, $.191 \mathrm{~mm}$.; width of metathorax, .244 mm.; width of abdomen, $.339 \mathrm{~mm}$.

Head flat-iron shaped, five-eighths again as long as wide, forehead rather quickly narrowed to the narrowly truncate front which bears at each side a clavate appendage and a hair of equal length. Temporal borders sub-parallel; occipital margin nearly straight. Antennal sinuses rather shallow. Trabeculæ quite prominent. Ocular projections missing. Antennal bands extend from the clavate appendages to the ocular flecks, interrupted by the conspicuous clypeal sutures and again by the inward-pointing hyaline bars arising at the trabeculæ. Temples narrowly margined with brownish. Occiput with a thickened, clear border. Clypeus clearly demarked by the forward-angulated suture, and split by a median suture. Temples pale amber. A large, pale, irregular shaped occipital signature. General color very pale. A hair at the clypeal suture, two before the trabeculæ, one at hind angle of antennal sinuses, one on hind third of temples. Antennæ reaching behind occipital border, faintly margined and banded.

Thorax about one-quarter as long as broad. Prothorax lenticular with weakly convex anterior and posterior borders, bisected faintly by a median clear bar which also bisects the metathorax. Bordered laterally by a pale margin. A weak spine at the posterior lateral angles. Metathorax pentagonal, the posterior margin strongly angulated on the first abdominal segment. Three long, pustulated hairs at the lateral angles. Like the prothorax, the general color is pale amber with colorless lateral borders. Legs rather small, pale.

Abdomen clavate, widest on the fourth segment. Posterior lateral angles of segments 2 to 8 with hairs as follows: Segment 2, a prickle; segment 3, a short spine; segment 4, a strong spine; segment 5, a long hair; segment 6, two long hairs; segment 7, two long hairs; segment 8, a short hair. Segment 9 has four short hairs and two prickles. Segments 1 to 8 inclusive are provided 
laterally with large rectangular sclerites, and segments 1 to 7 have in addition a narrow, brownish, lateral plate.

Type: Catalogue No. 21366. U. S. Nat. Mus.

Lipeurus bishoppi sp. nov.

Four males and one female (Bishopp No. 4995) from domestic geese, Hamburg, Miss., December 3, 1915, coll. W. E. Dove.

This species is probably nearest $L$. temporalis $\mathrm{N}$., of the merganser, and it also bears some resemblance to $L$. squalidus N., of ducks, and to $L$. constrictus Kell., of scoters.

Description of Male. Total length, $3.05 \mathrm{~mm}$.; length of head, $.664 \mathrm{~mm}$.; length of prothorax, .186 mm.; length of metathorax, $.431 \mathrm{~mm}$.; length of abdomen, $1.771 \mathrm{~mm}$; width of head between eyes, $.442 \mathrm{~mm}$; width of prothorax, $.326 \mathrm{~mm}$.; width of metathorax, $.431 \mathrm{~mm}$; width of abdomen, .524 $\mathrm{mm}$.

Head just half again as long as wide, forehead converging to the sharply rounding front, antennal sinuses shallow, trabeculæ rather prominent, ocular flecks lacking, temples converging from the eyes to the concave occiput. Six heavy spines along the lateral half of the front and anterior half of forehead, the third of which is heaviest; a short hair before trabecular, a hair on the eye, four prickles along the temples and a long hair on the hind third of same. Antennal bands occur as thin, hyaline borders which before the trabeculæ give off a short, swollen, posterior-directed bar, and at the hind border of the antennal sinuses sends off a similar, inward-pointing bar, general color pale, smoky amber. Antennæ strong, reaching to the middle of the prothorax, segment 3 with a strongly developed hooked process.

Thorax three-sevenths again as long as wide. Prothorax rectangular, front margin quite strongly convex, hind margin weakly convex. Narrow, brownish, submarginal bands curve backward and inward, nearly meeting on the median line; coxal markings showing faintly through; general color pale amber. A prickle and a short hair at the posterior lateral angles. Metathorax quadrilateral, slightly constricted near the middle, posterior margin weakly concave. General color same as prothorax, with a brown-bordered, black spot at each lateral constriction. Six long stiff hairs on each lateral third of the hind margin. Legs strong, brownish-yellow. 
Abdomen linear-clavate, widest on the fourth and fifth segments, segment 1 short and lenticular. Posterior lateral angle supplied with hairs as follows: Segment 2, one prickly; segment 3, two weak hairs; segment 4, a short and a long hair; segment 5 , one short and two long hairs; segment 6, two long hairs; segment 7, two longish hairs; segment 8, two long hairs. The terminal segment is shallowly notched on each side of which is a prickle and a short hair; a smoky blotch involves most of the segment. At the anterior angles of each of segments 2, 3, 4 and 5 is a black, triangular blotch; general color transparent.

Type: Catalogue No. 21365. U. S. Nat. Mus.

Lipeurus aberrans sp. nov.

Three females and four males (Bishopp No. 7228) from the Texas bob-white (Colinus virginianus texanus), Columbus, O., January 25, 1917, coll. F. C. Bishopp. These birds had been introduced for experimental purposes from a point in Mexico opposite Eagle Pass, Texas.

This aberrent species is nearest $L$. docophoroides Piag., of the California partridge (Callipepla californica) from which it differs radically in the shape of head, prothorax and metathorax.

Description of Male. Total length, $2.18 \mathrm{~mm}$.; length of head, $.619 \mathrm{~mm}$.; length of prothorax, .210 mm.; length of metathorax, $.240 \mathrm{~mm}$.; length of abdomen, $1.112 \mathrm{~mm}$.; width of head, .532 $\mathrm{mm}$; ; width of prothorax, $.370 \mathrm{~mm}$.; width of metathorax, .608 $\mathrm{mm}$.; width of abdomen, $.741 \mathrm{~mm}$.

Head a trifle longer than wide, the fore margin forming a nearly even curve between the trabeculæ which are very strongly developed. Antennal sinuses deep. Ocular projections very conspicu-

Explanation of Plate.

\section{Plate VI.}

Fig. 1. Female of Lipeurus texanus sp. nov.

2. Male of Lipeurus bishoppi sp. nov.

3. Right leg III of female of Lipeurus texanus sp. nov. (viewed ventrally).

4. Left leg III of male of Lipeurus bishoppi sp. nov. (viewed ventrally). 
ous. Temples at first parallel and then rounding convergingly to meet, without angles, the nearly straight occiput. Antennal bands black, conspicuous, paling just before ocular blotches which extend inward and forward as a narrowing bar; ocular bands replaced by pale underlying sickle shaped bars; temples margined by a black, crenate band which extends paler along the occipital margin; excepting the smoky colored, spindle shaped occipital signature, the brown osophageal sclerite and mandibles, the general color is pale. Six prickles and two short hairs along the frontal border, a prickle and two short hairs before the trabeculæ, a long hair from over the eye, two long hairs and four prickles from the temples. Antennæ very stout, basal segment about equalling all others, third segment brownish and with strong, hooked appendage, second segment with weak but well defined appendage.

Therax one-third again as wide as long. Prothorax somewhat trapezoidal, the posterior margin rather strongly convex. Lateral margins bordered with heavy, black bands from the anterior ends of which narrow, fainter underlying bars extend backward and inward; a pale blotch occurs at each posterior lateral angle, and a small, triangular blotch lies directly behind the occiput. A long hair arises at each posterior angle. Metathorax pentagonal the hind margin sharply angulated on first abdominal segment; lateral sides diverging very abruptly. A dark interrupted, submarginal band extends from the prothorax to the black, pustulated blotch at the posterior lateral angle, and a triangular blotch involves each temple; excepting these markings and an anterior median pair of faint blotches, the general color is pale. A spine and a short hair at the lateral angles, and five long, pustulated hairs on each lateral third of posterior margin. Legs normal, brown bordered and banded.

Abdomen clavate-ovate, widest on fourth segment, contracted abrupt at the seventh segment. Segments 1 to 7 inclusive with narrow, brownish, lateral plates over-reaching hind end of plate next ahead. Segments 1 to 7 each with a chestnut-brown transverse blotch which are parted on the median line; those of segments 1 to 6 with a large hyaline spot at the sides, and in addition those of segments 2 to 7 with a small, clear, circular spot at their centers. Segments 3 to 8 with hairs at the posterior lateral angles as follows: Segment 3, a short hair; segment 4, two long hairs; 
segment 5, three long hairs; segment 6 , three long hairs; segment 7, a short and a long hair; segment 8, three long hairs. Segments 1 to 7 with series of transverse short hairs as follows: Segment 1, 24; segment 2,21 ; segment 3,29 ; segment 4 , 29 ; segment 5 , 26 ; segment 6,18 ; segment 7, 12. Along each side of terminal segment a fringe of ten successively shorter hairs. An irregularshaped genital blotch involves segments 8 and 9.

Type: Catalogue No. 21364. U. S. Nat. Museum.

Lipeurus lineatus sp. nov.

One male (Bishopp No. 4063a) from quail, Hamburg, Miss., January 5, 1915, coll. W. E. Dove. The specimen is somewhat shrunken so that excepting, probably, the head, a proper restoration would show the body parts rather ampler than indicated in the camera lucida drawing accompanying.

This species is nearest $L$. variabilis $\mathbf{N}$. of the domestic fowl, but differs from it in the head markings, shape of metathorax, shape and markings of abdomen, and in the nature and distribution of hairs.

Description of Male. Total length, $2.05 \mathrm{~mm}$.; length of head, $.480 \mathrm{~mm}$.; length of prothorax, .133 mm.; length of metathorax, $.231 \mathrm{~mm}$.; length of abdomen, $1.193 \mathrm{~mm}$; width of head, .302 mm.; width of prothorax, .196 mm.; width of metathorax, .290 mm.; width of abdomen, $.267 \mathrm{~mm}$.

Head subrectangular, three-fifths again as long as wide. Widest just before antennæ. Forehead bullet-shaped, with a dusky border darkest midway along the margin; antennal sinuses deep; trabeculæ fair sized; temple margins gradually diverging and meeting the rather deeply emarginate occiput without angles. Eyes not protruding beyond margin; ocular flecks conspicuous; antennal bands most distinct just before antennæ, interrupted across antennal bases and reappearing to form ocular blotches; temples bordered with pale brown bands; very faint occipital bands. With exception of foregoing markings and the chestnut brown mandibles, the general color is transparent. Two longish hairs on front, two longish and one long hair at beginning of forehead, three short hairs before antennæ, two shortish hairs on temple, two prickles dorsally before occipital emargination, and two strong spines dorsally near center of forehead. Antennæ very 
strong, reaching behind hind margin of prothorax; basal segment with strong spur posteriorly, third segment with a spur-like projection.

Thorax one-quarter again as long as wide. Prothorax rectangular, posterior margin nearly straight, bordered laterally by chestnut brown bands from which faint, narrow, underlying bands extend inward to near the median line. A weak hair on each side of posterior margin midway to center. Metathorax roughly quadrate, posterior margin slightly rounded. Submarginal, brownish bands ending posteriorly at the smoky-ringed pustulations on the posterior lateral angles which give rise to five longish to long hairs. Anterior and posterior angles each with smoky blotches, and median sternal blotches showing through; general color pale. A weak hair on the hind margin just within the pustulations. Legs very long, smoky bordered.

Abdomen (in the contracted specimen) linear, noticeably constricted on the third and fourth segments, widest on the first segment. Segments 1 to 8 inclusive with wide, chestnut brown lateral bands. Segments 2 to 8 with hairs at the posterior lateral angles as follows: Segment 2, a long hair; segment 3, a long hair; segment 4, a prickle; segment 5 , a short spine; segment 6 , a short spine; segment 7, a longish hair; segment 8 , two extremely long, slender hairs. Segment 8 gives rise at the middle of lateral plate to a prickle and a very long hair, and at the posterior margin two pustulations give rise each to two short hairs. Segment 9 bears a pair of terminal prickles. Segments each 1 to 8 inclusive bear centrally a pair of dorsal spines. Faint lateral blotches, which become slightly darker posteriorly, almost totally involve each of the segments. A faint genital blotch involves segments 7,8 and 9.

Type: Catalogue No. 21362. U. S. Nat. Mus.

Lipeurus clavatus sp. nov.

One female (Bishop No. 4063 ${ }^{\text {b }}$ ) from quail, Hamburg, Miss., January 5, 1915, coll. W. E. Dove.

This species is closest to L. snodgrassi Kell., of the hummingbird, and L. introductus Kell., of the pheasant, but not at all resembling the known Lipeuri of the partridge or the Bob-white.

Description of Female. Total length, $2.03 \mathrm{~mm}$.; length of head, 
$.477 \mathrm{~mm}$.; length of prothorax, .126 mm.; length of metathorax, $.243 \mathrm{~mm}$.; length of abdomen, $1.170 \mathrm{~mm}$.; width of head across temples, $.288 \mathrm{~mm}$; width of prothorax, $.225 \mathrm{~mm}$., width of metathorax, $.360 \mathrm{~mm}$; ; width of abdomen, $.477 \mathrm{~mm}$.

Head two-thirds again as long as wide, projectile-shaped. Antennal sinuses extremely shallow. Ocular projections slightly noticeable. Forehead and front margined with a pale, narrow band which turns inward before the antennæ to form a pair of pitchy spots; commencing at the eyes the temples are margined with a chestnut colored band which gradually pales posteriorly; a pair of pitchy spots occur at the occipital border; with these exceptions, and the smoky temples, the general color is pale. Six prickles on forehead between center of front and trabeculæ; four prickles and a long hair on the temples. Antennæ normal.

Thorax about as wide as long. Prothorax roughly trapezoidal, pale straw-color, with narrow, brown, submarginal bands; posterior margin nearly straight; a weak spine before posterior lateral angles. Metathorax trapezoidal, posterior border straight, general color same as prothorax, sides mostly pale-bordered with submarginal brownish bands; four very long hairs at each posterior lateral angle. Legs unusually small, pale.

Abdomen clavate-elliptic, widest on the fourth segment. Segments 2 to 7 each with blackish-brown lateral bands which widen slightly at their anterior and posterior ends into brownish, inwardpointing blotches; segments 2 to 7 inclusive with extremely faint transverse blotches, those of segments 3 to 7 each bisected medially; segment 8 with a slightly darker transverse blotch. Hairs at the

Explanation of Plate.

Plate VII.

Fig. 1. Male of Lipeurus aberrans sp. nov.

2. Male of Lipeurus lineatus sp. nov.

3. Female of Lipeurus clavatus sp. nov.

4. Left leg II of male of Lipeurus aberrans sp. nov. (viewed ventrally).

5. Right leg III of male of Lipeurus lineatus sp. nov. (viewed ventrally).

6. Right leg III of female of Lipeurus clavatus sp. nov. (viewed ventrally). 
posterior lateral angles as follows: Segment 2, a short hair; segment 3, a long hair; segment 4, a long hair; segment 5, two long hairs; segment 6, two long hairs; segment 7, a long hair; segments 3 to 7 each with a long hair arising just mediad of the lateral angles; segment 8 with two long hairs laterally; a pair of long, subterminal hairs before the deeply emarginate posterior tip.

Type: Catalogue No. 21367. U. S. Nat. Mus.

\title{
NOTES ON SOME NEW SPECIES OF THE GENUS
} DIOCTRIA (ASILIDA).

\author{
By Nathan Banks, \\ Museum of Comparative Zoology, Cambridge, Mass.
}

Our Eastern specimens of the genus Dioctria have all been placed in the species albius Walker. In examining our specimens I note, however, two types of male genitalia. In one, the northern form, the superior plate has two broad lobes, sometimes standing out flat, sometimes rolled down over the other parts; in the other more southern specimens the superior plate is divided into two long tapering parts ending in a knob-like enlargement, with a tooth on the inner surface and a pencil of yellow hair on the outer edge. The northern form is the true albius Walker; it has the third antennal joint short, and with a very short style; the mystax is black; the body is rather longer than in the southern forms. The southern forms I divide into two species, one with the antennæ like D. albius; the other with the third joint and style much longer; both are new.

\section{Dioctria brevis sp. nov.}

Black, bronzy as in D. albius, and in general similar to that species; the third antennal joint barely if any longer than in D. albius. It differs at once, in the shape of the superior plate of the male genitalia, having two long tapering divisions, rather swollen at their tips, with a sharp, slender tooth on the inner side shortly before tip, and on the outer side a pencil of yellow hair.

Specimens are 8 to $10 \mathrm{~mm}$. long, and come from Sea Cliff, N. Y.; Medina, Ohio; Englewood, N. J.; and north fork Swannanoa River, Black Mountains, N. C.

Type: M. C. Z. 10032. 
Psyche, $191 \%$. Vol. XXIV, Plate V.

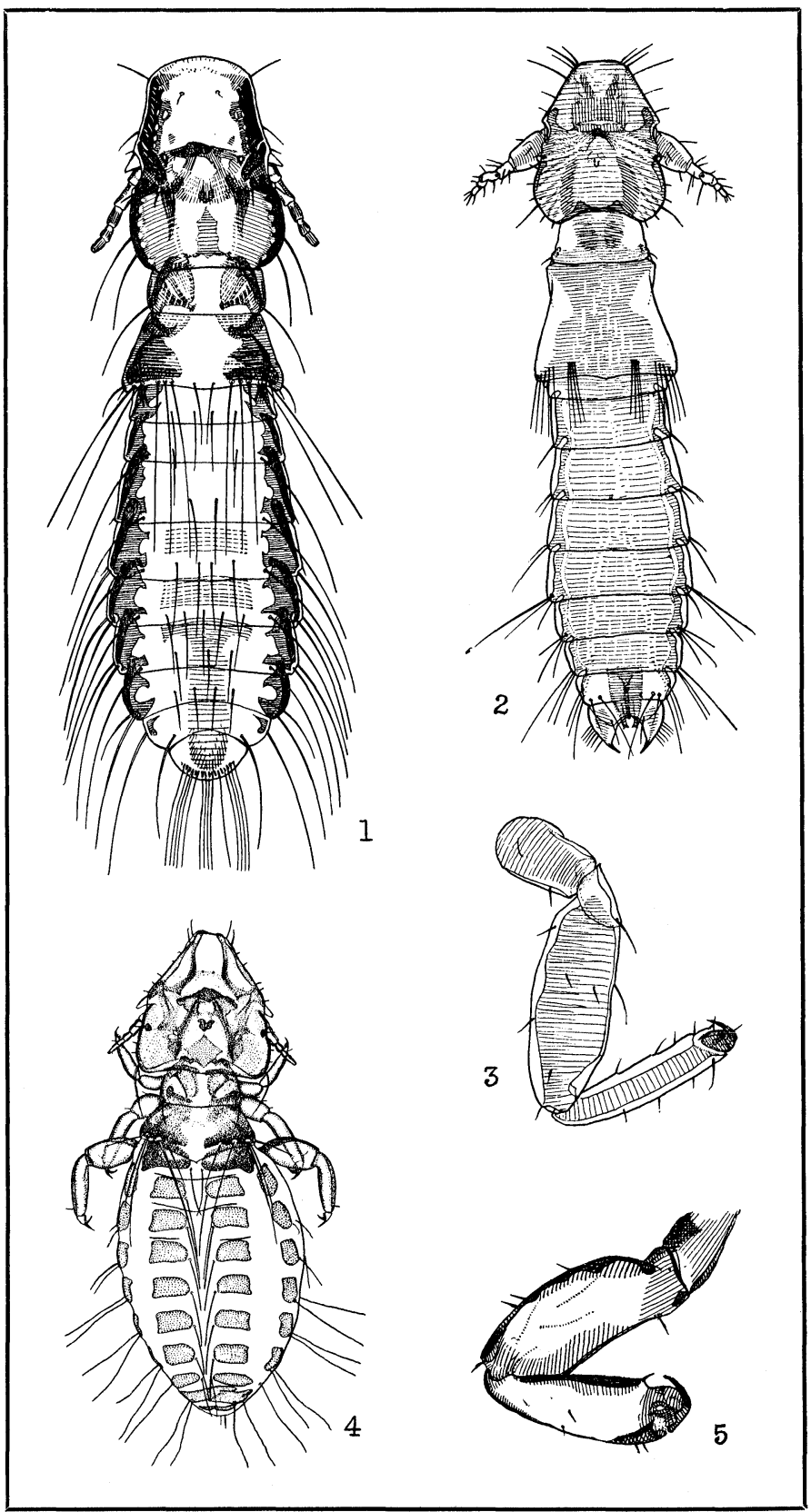

MCGREGOR-Mallophaga of the Genus Lipeurus. 

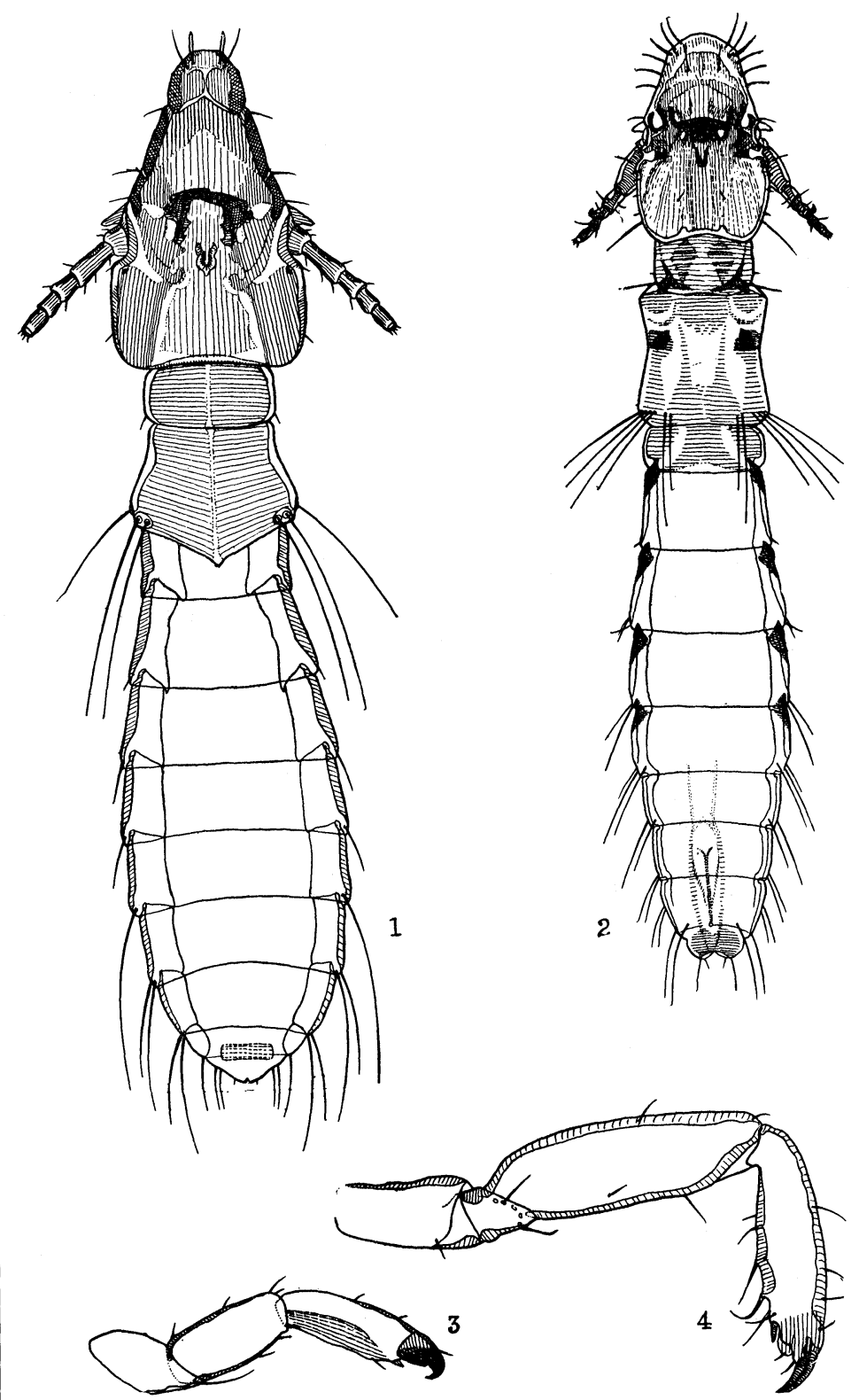

MCGREGOR-Mallophaga of the Genus Lipeurus. 


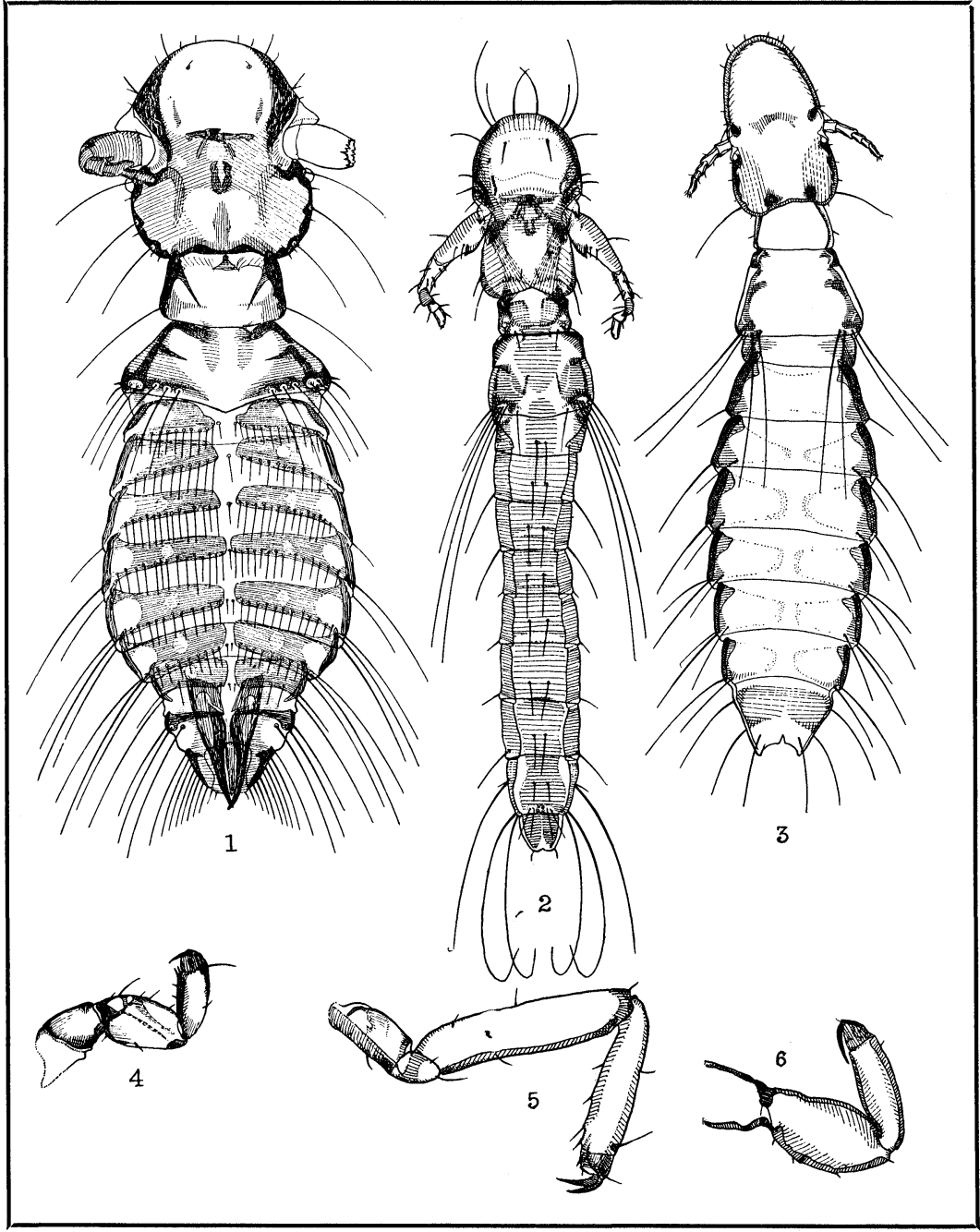

MCGREGor-Mallophaga of the Genus Lipeurus. 

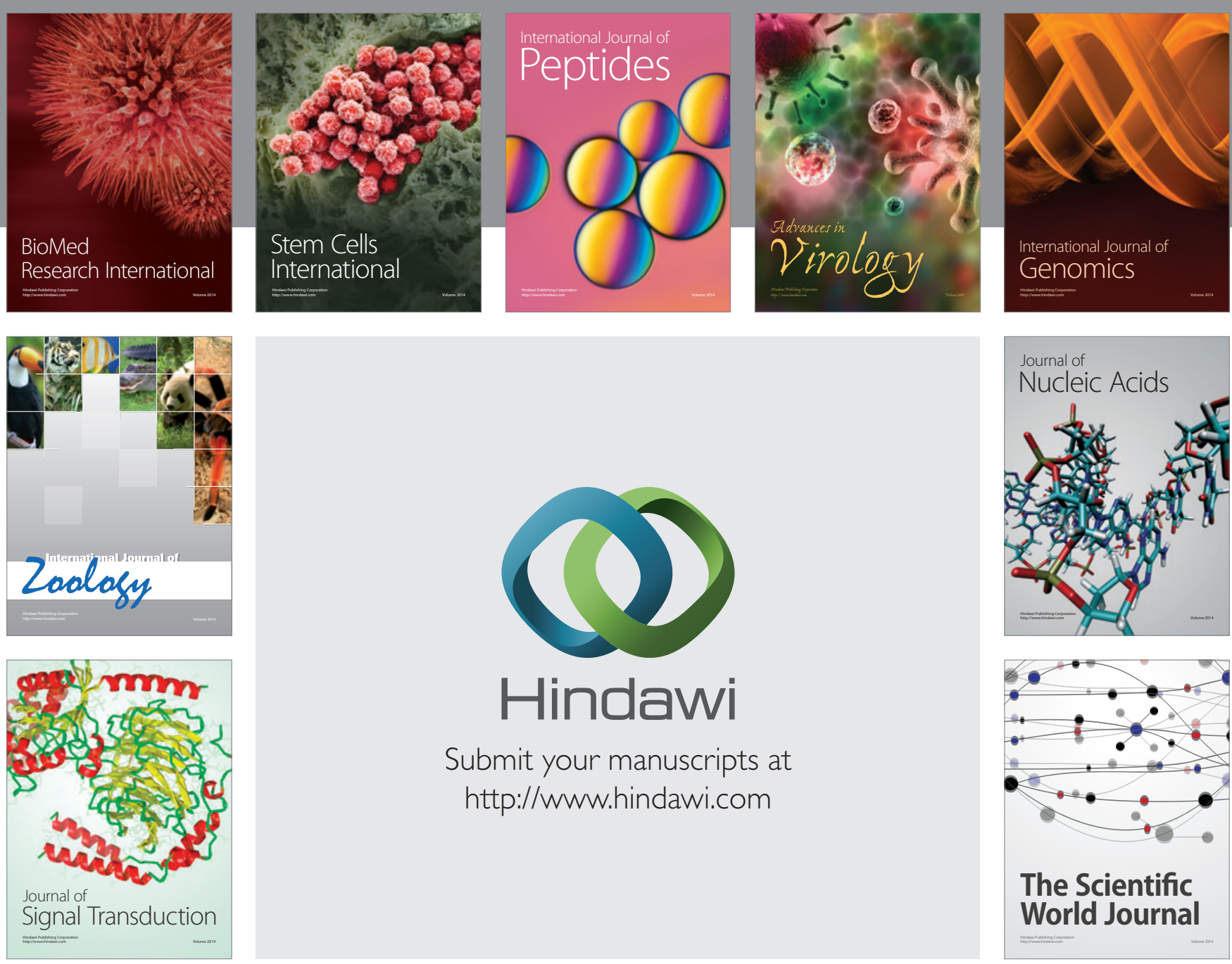

Submit your manuscripts at

http://www.hindawi.com
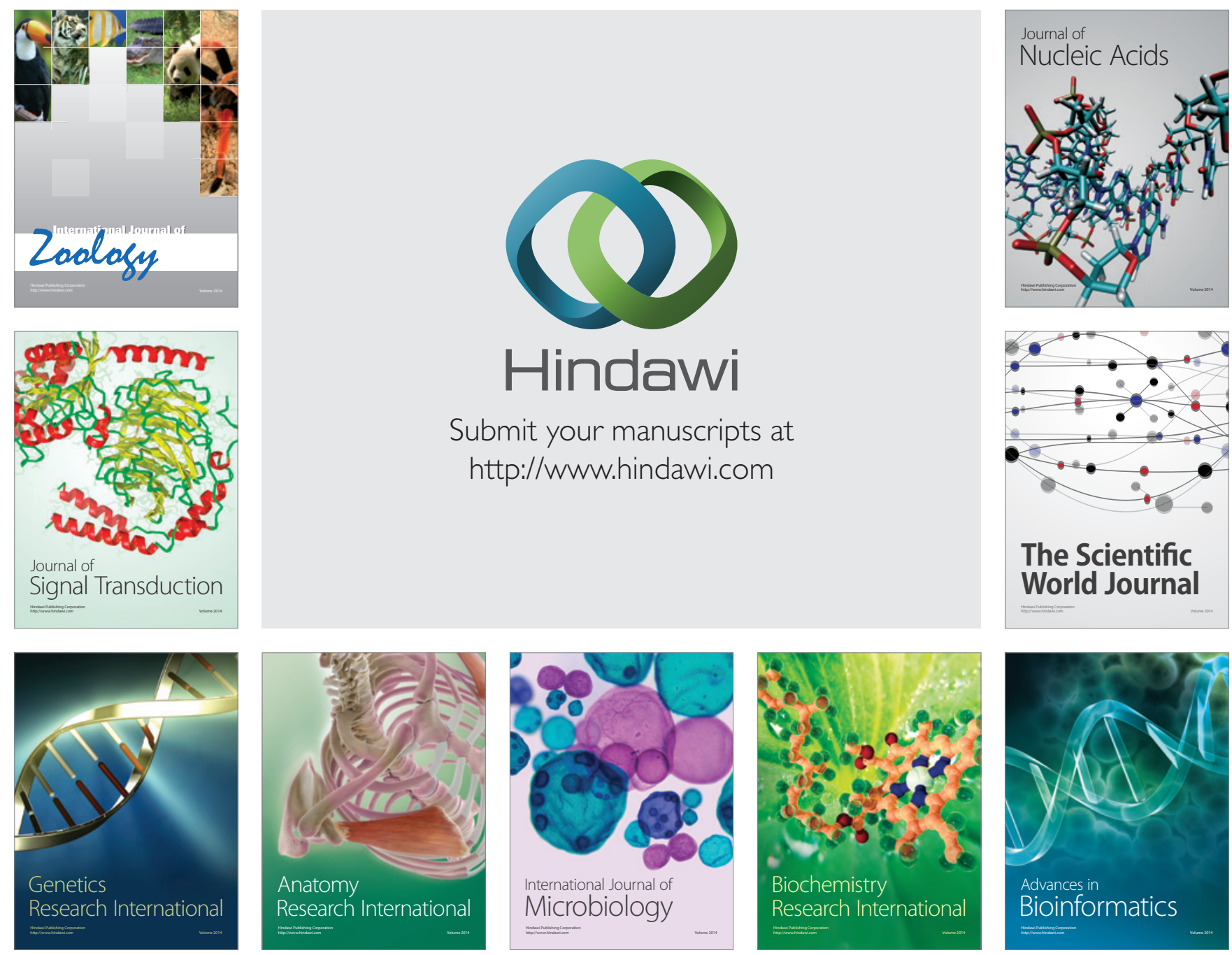

The Scientific World Journal
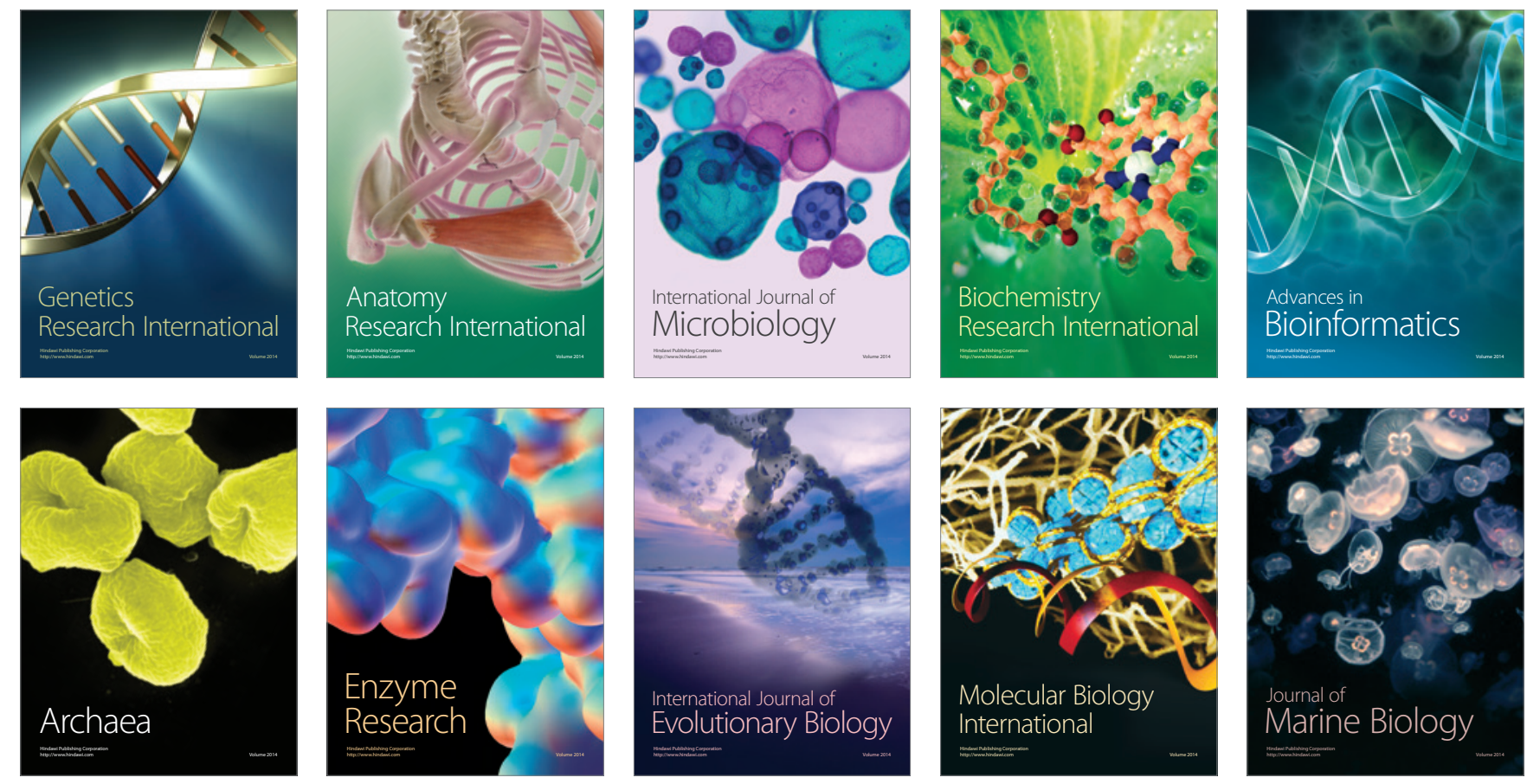